\title{
Study on Deformation and Failure Characteristics of Surrounding Rock of Overlying Roadway under Upward Mining in the Deep Mine
}

\author{
Teng-Gen Xiong $\mathbb{D}^{D}$, Ju-Cai Chang $(\mathbb{D}$, Kai He, Ya-Feng Su, and Chao Qi \\ School of Mining Engineering, Anhui University of Science and Technology, Huainan, 232001 Anhui, China \\ Correspondence should be addressed to Ju-Cai Chang; x1216mine@163.com
}

Received 29 May 2021; Accepted 3 July 2021; Published 28 July 2021

Academic Editor: Zhijie Wen

Copyright (c) 2021 Teng-Gen Xiong et al. This is an open access article distributed under the Creative Commons Attribution License, which permits unrestricted use, distribution, and reproduction in any medium, provided the original work is properly cited.

\begin{abstract}
To study the impact of mining of the lower protective layer on the deformation and failure characteristics of the upper roadway, these characteristics of an 879 gas drainage roadway were studied and analyzed during the mining of the II 1051 working face of the Zhuxianzhuang coal mine using similar simulation experiments and numerical simulation methods. The results indicate that with the continuous excavation of the working face, the range of impact of the mining stress gradually spreads and exceeds the level of the roadway. At the present time, the roadway is in a mining stress-rising area. The two sides of the roadway are sheared, and the roof and floor are under tension-shear composite failure. The floor is the most gravely damaged-the depth of its damage is $2.5 \mathrm{~m}$, and the depths of damage on either side and of the roof are approximately 1-2 $\mathrm{m}$. During the advancing process of the working face, the deformation of the roadway increases slowly at first, then increases sharply, and tends to be stable thereafter. The deformation of the floor is the largest, followed by those of the two sides and the roof; the values are 800 , 400 , and $300 \mathrm{~mm}$, respectively.
\end{abstract}

\section{Introduction}

The depletion of shallow coal resources in China has led to increasing mining depth in various mining areas, and the problems of coal and gas outbursts in coal mines are also increasing. According to the characteristics of "two low and one high" of coal seam gas, several scholars at home and abroad have found that protective seam mining is the most economical and effective method of preventing coal and gas outbursts [1-6]. Although protective seam mining causes the stress redistribution of the protected seam, leading to a sharp drop in the gas pressure, this, in turn, reduces the risk of gas outburst and also causes the movement and deformation of as well as transverse and longitudinal cracks in the overlying strata. It also leads to the formation of stressreduction and -rise areas. Regardless of whether the roadway is laid on the stress-reduction or -rising area, the stress distribution in the surrounding rock changes [7]. The redistribution of the stress in the surrounding rock promotes the continuous development of cracks in the areas surrounding the roadway, leading to breakage of the surrounding rock and a reduction in the bearing capacity. This further causes deformation in and instability of the roadway, which renders it difficult to maintain.

In view of the deformation and failure characteristics of the overlying strata caused by the mining of the lower protective layer, a significant amount of research has been carried out. Jiao et al. [8], Cao et al. [9], and Bai and Hu [10] studied the movement and deformation characteristics of the overlying strata during the mining process of the lower protective seam. Shun et al. [11] and Xiong et al. [12] analyzed the migration rule of overburden after mining. Wang et al. [13] and Xue et al. [14] formulated a fracture evolution law for the overlying strata following coal mining. Tang et al. [15], Zhang et al. [16], Xu and Han [17], and Zhang et al. [18] analyzed the stress distribution and deformation of the protected layer during the mining process of the lower protective layer. Yang et al. [19] studied the deformation and failure 
characteristics of the overlying strata, development law of mining stress and fracture, and size of the stress release area. Zhang et al. [20] studied the characteristics of strata failure fracture, fracture evolution, and subsidence deformation in the process of the upward mining of deep coal seams. They further analyzed the relationship between the strata subsidence deformation curve and the strata fracture, fracture development, and stress state. Liu et al. [21] analyzed the law governing the development of overlying strata fractures caused by thin protective seam mining. Huang et al. [22] focused on the comprehensive morphological characteristics of the fracture zone formed by the mining of the lower coal seam and the distribution of the concentrated stress in the surrounding rock. Liu and Chen [23] studied the deformation of coal seam pressure relief, development of mining fracture, protective effect of pressure relief, discharge of pressure relief gas, gas drainage, and outburst prevention and control laws. Qian et al. [24] studied the stress distribution law of the overlying strata with respect to the various support parameters of the upper protective layer and obtained the range of impact of the stress release and concentration areas of the overlying strata.

There have also been several developments in the study of the stability of the overlying roadway owing to the mining of the lower protective layer. Qian et al. [24] used the FLAC numerical simulation software to analyze the effect of upward mining on the stability of the overlying roadway with respect to the various support parameters of the upper protective seam and found that the vertical stress, plastic zone, and displacement of the sidewall on one side of the roadway in the upper protective seam were greater than those on the side near the underlying goaf. Xie et al. [25] studied the impact of the repeated mining of multiple coal seams on the deformation of roof roadways. Wang et al. [26] studied the temporal and spatial evolution laws of the stress and fracture fields in a roof coal roadway after pressure-relief mining in a lower coal seam and found that the superimposed stress formed by the underlying mining and roadway excavation determines the stress distribution and fracture evolution characteristics of the rock surrounding the roadway. Zhang et al. [27] used physical experiments to study the deformation and failure characteristics of the roof roadway in various areas and obtained the similar characteristics of roadways in "three zones": in the collapse zone, the roadway indicated strong roof collapsing and floor bulging; the cracks in the rock surrounding the roadway in the fracture zone were significantly reduced, but the mining damage was still significant; and the deformation and failure of the rock surrounding the roadway in the bending subsidence zone were not evident. Zhou et al. [28] used the UDEC discrete element numerical simulation software to study the failure characteristics of the rock surrounding a coal roadway in the fracture zone and found that the failure was most evident in the roof and floor of the roadway, followed by the failure of the side of the roadway near the working face.

The literature referred to above primarily investigated the deformation and failure characteristics and stress distribution of the overlying strata and coal roadway in the mining process of the lower protective seam. However, little infor- mation is available on the deformation and failure law of the rock roadway outside the "three zones" and adjacent to the working face. However, the overlying 879 gas drainage roadway of the II 1051 working face in the Zhuxianzhuang coal mine is located in the rock strata outside the "three zones," which is significantly deformed and damaged by the mining of the working face. Based on the abovementioned conditions, through similar simulation experiments and numerical simulations and considering the overlying 879 gas drainage roadway of the Zhuxianzhuang coal mine II 1051 working face of the Huaibei Mining Group as the engineering background, in this study, the deformation and failure characteristics of the upper roadway during the mining of the lower protective layer are investigated. Further, the law that governs the impact of the deformation and failure characteristics of the overlying strata on similar characteristics of the upper roadway and the instability mechanism of the roadway is summarized.

\section{Project Profile}

The Zhuxianzhuang mine is located in Suzhou City, Anhui Province, China. The 879 gas drainage roadway, to be studied in this study, is located in the II 5 mining area. The mineable coal seams in the mining area were identified as No. 8 and No. 10 coal. The No. 10 coal seam lies under the No. 8 coal seam, the distance is approximately $78 \mathrm{~m}$, and the coal seam dip angle is approximately $20^{\circ}$. The No. 10 coal seam is used in protective seam mining; the thickness of the coal seam is $0.97-3.2 \mathrm{~m}$, and its structure is relatively simple. The 879 gas drainage roadway is arranged $40-45 \mathrm{~m}$ above the roof of the No. 10 coal seam, with a horizontal distance of $5 \mathrm{~m}$ from the left coal wall of the working face, serving as gas drainage for the No. 8 coal seam, as depicted in Figure 1(a). The position of the rock surrounding the roadway and the rock properties of the roof and floor of the roadway are depicted in Figure 1(b). According to the geological histogram, it can be seen that the direct bottom of the roadway is made of mudstone, the two sides are made of fine sandstone, and the lithology of the floor is poor. Therefore, under high stress and dynamic load, the floor is more likely to be damaged than either side.

To reduce the amount of roadway excavation required, the 879 gas drainage roadway was used as the main roadway for the eight coal mines. When the lower protective layer was mined, the overlying strata moved and deformed under the impact of mining, the original stress balance state was broken, the coal and rock mass near the working face were destroyed, and the stress on the surrounding rock was redistributed to achieve a new stable state. In the process of relief of pressure from the upper coal seam, the strength of the surrounding rock of the upper roadway was weakened, leading to the fracture and instability of the rock surrounding the roadway, which is difficult to maintain and has a significant impact on the safety of the mine. Therefore, it is necessary to study the characteristics, summarize the mechanism of roadway deformation and failure, and provide guidance for reasonable roadway support design. 


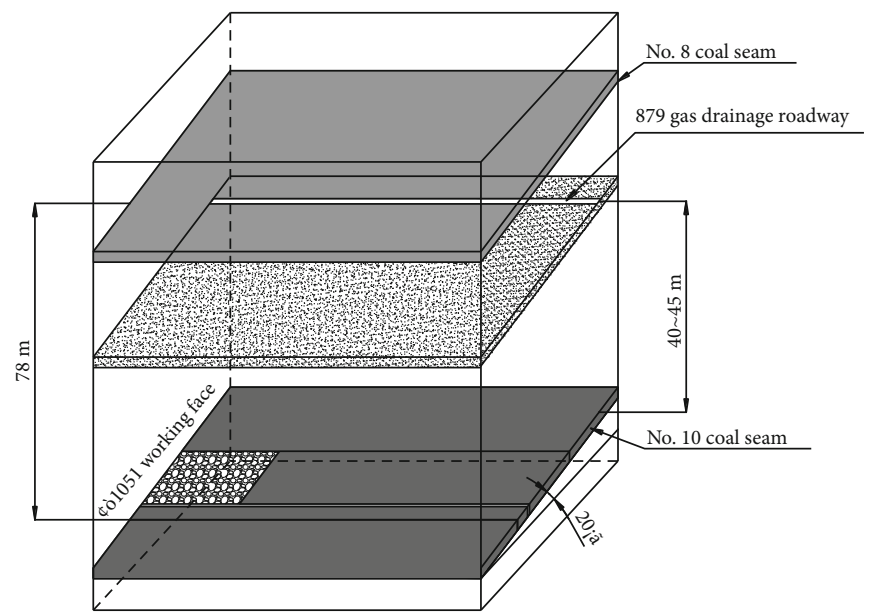

(a)

\begin{tabular}{|c|c|c|c|}
\hline Histogram & $\begin{array}{l}\text { Average } \\
\text { thickness } \\
(\mathrm{m})\end{array}$ & Rock name & Rock properties \\
\hline & 8.0 & No. 8 coal & $\begin{array}{l}\text { It is black, and the upper part is massive, } \\
\text { belonging to semibright type }\end{array}$ \\
\hline & 2.0 & Mudstone & $\begin{array}{l}\text { It is grayish-black, massive, containing plant } \\
\text { fossil fragments }\end{array}$ \\
\hline & 6.0 & Fine sandstone & $\begin{array}{l}\text { It is gray or grayish-white, with discontinuous } \\
\text { micro oblique bedding }\end{array}$ \\
\hline & 5.7 & $\begin{array}{l}\text { Medium } \\
\text { sandstone }\end{array}$ & $\begin{array}{l}\text { It is grayish-white, with horizontal microwave } \\
\text { bedding. }\end{array}$ \\
\hline 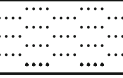 & 4.0 & Siltstone & $\begin{array}{l}\text { It is dark gray, with horizontal microwave } \\
\text { bedding, containing carbon chips }\end{array}$ \\
\hline $7 \%$ & 5.0 & Alumine & $\begin{array}{l}\text { It is light gray, and the upper part is the pure } \\
\text { aluminum, and the lower part contains siderite } \\
\text { and purplish-red plaque }\end{array}$ \\
\hline & 6.0 & Fine sandstone & $\begin{array}{l}\text { It is gray orbluish-gray, with discontinuous } \\
\text { micro-oblique bedding }\end{array}$ \\
\hline$-1-1$ & 3.0 & Mudstone & $\begin{array}{l}\text { It is light gray, containing argillaceous enclaves } \\
\text { and plant fossil fragments }\end{array}$ \\
\hline 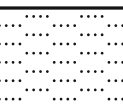 & 5.5 & Siltstone & $\begin{array}{l}\text { It is dark gray, dense, brittle, and fissured, with } \\
\text { black mudstone and carbonaceous in the middle }\end{array}$ \\
\hline $\begin{array}{ll}\cdots \cdots \cdots \\
\cdots \cdots \cdots \\
\cdots \cdots \cdots \\
\cdots \cdots\end{array}$ & 8.0 & Fine sandstone & $\begin{array}{l}\text { It is light gray with developed fissures in the } \\
\text { middle, a hidden horizontal bedding, and a } \\
\text { massive carbonaceous argillaceous belt }\end{array}$ \\
\hline \begin{tabular}{l}
$\cdots \cdots \cdots \cdots \cdots$ \\
$\cdots \cdots$ \\
\hdashline$-\cdots$
\end{tabular} & 2.6 & Sandy mudstone & $\begin{array}{l}\text { It is gray, with siderite inclusions, containing } \\
\text { carbonized plant debris }\end{array}$ \\
\hline $\begin{array}{l}\cdots \cdots \cdots \cdots \cdots \cdots \\
\cdots \cdots \cdots \cdots \cdots \\
-\quad-\quad-\end{array}$ & 2.3 & Fine sandstone & $\begin{array}{l}\text { It is grayish-green, dense, with siderite and } \\
\text { nodules at the top }\end{array}$ \\
\hline$\overline{-}^{-}-\overline{-}$ & 3.5 & Mudstone & $\begin{array}{l}\text { It is greenish-gray, with a well-developed sliding } \\
\text { surface }\end{array}$ \\
\hline$\cdots \cdots \cdots \cdots \cdots \cdots$ & 4.0 & Siltstone & $\begin{array}{l}\text { It is blackish-gray, dense, with black argillaceous } \\
\text { rock in the middle }\end{array}$ \\
\hline 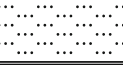 & 5.0 & Fine sandstone & $\begin{array}{l}\text { It is gray and massive, and its horizontal bedding } \\
\text { is developed }\end{array}$ \\
\hline$\because \cdots$ & 5.0 & $\begin{array}{c}\text { Medium } \\
\text { sandstone }\end{array}$ & $\begin{array}{l}\text { It is grayish-white, mainly quartz, with } \\
\text { argillaceous cementation and fragile. }\end{array}$ \\
\hline & 2.5 & No. 10 coal & $\begin{array}{l}\text { It is black and fragmentary, dominated by bright } \\
\text { coal }\end{array}$ \\
\hline
\end{tabular}

(b)

FIgURE 1: Comprehensive histogram depicting the spatial location and geology of roadway. 


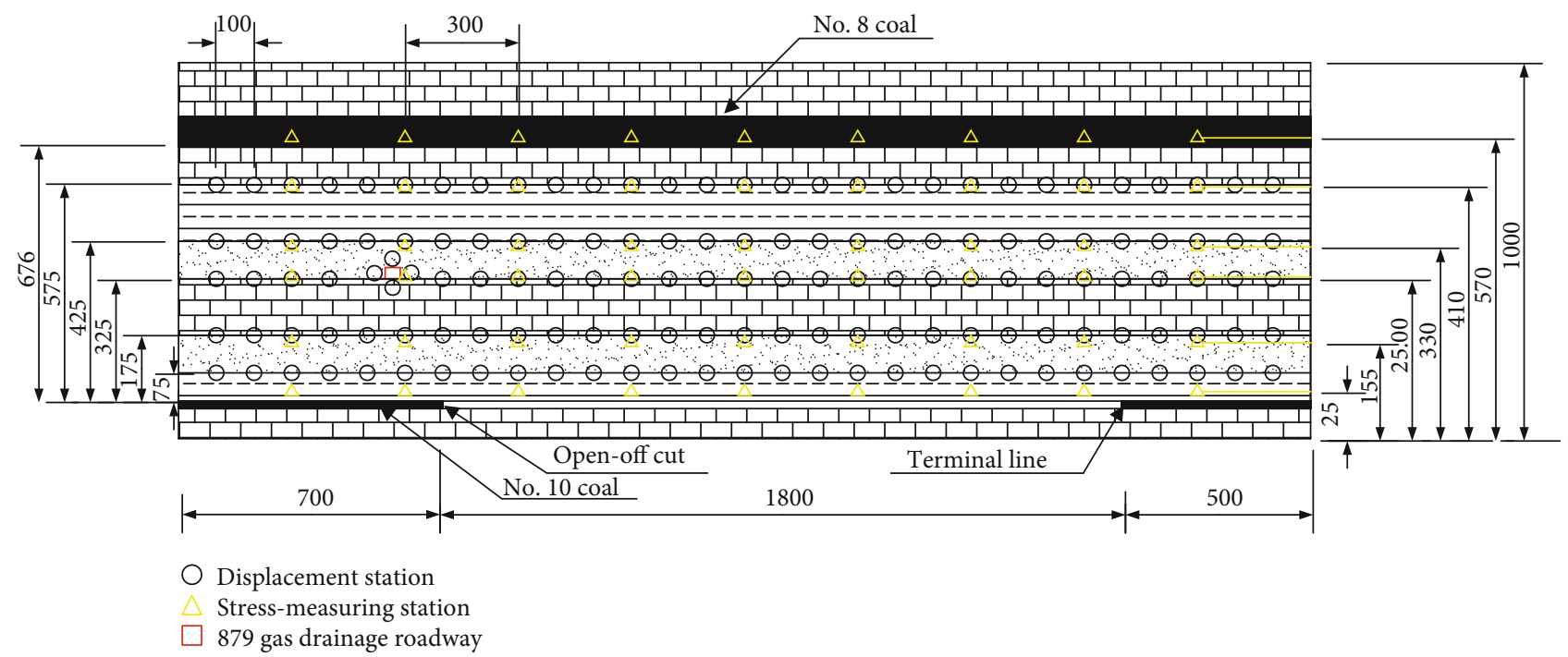

FIgUre 2: Model sensor layout.

\section{Study on Migration and Stress Distribution of Overlying Strata in Upward Mining}

3.1. Similar Material Model Design. According to the geological conditions and similarity theory, the geometric similarity ratio was $C_{L}=1: 100$, bulk density similarity ratio was $C \gamma$ $=1: 1.67$, and stress similarity ratio was $C_{\sigma}=1: 167$. Therefore, the model size was determined as length $\times$ width $\times$ height $=3000 \mathrm{~mm} \times 300 \mathrm{~mm} \times 1300 \mathrm{~mm}$, and the mining thickness was determined as $2.5 \mathrm{~cm}$. On either side of the model, 70 and $50 \mathrm{~cm}$ boundary coal pillars were set. In the test, fine sand was selected as the aggregate, gypsum powder and lime powder were used as cementing materials, mica powder was used for layered laying between each rock layer, and the remaining weight of the upper part of the model was imposed by an additional counterweight.

3.2. Test Data Monitoring. To monitor the changes in the stress and displacement of the overlying strata and rock surrounding the 879 gas drainage roadway when the model mines the lower protective layer, six stress observation lines were buried from the bottom to top; the distances between the lines and the No. 10 coal roof were 2.5, 15.5, 15.5, 33, 41,57 , and $70 \mathrm{~cm}$. Simultaneously, five displacementmeasuring lines were set on the surface of the model. The distances between the measuring lines and the roof of the No. 10 coal seam were $7.5,17.5,32.5,42.5$, and $57.5 \mathrm{~cm}$. One measuring point was arranged every $10 \mathrm{~cm}$ of the measuring line, and another four displacement-measuring points were arranged around the roadway. The distribution of the measurement points is depicted in Figure 2.

During the test, a BX120-50AA resistance strain gauge and a CM-2B strain gauge were used as the stress acquisition devices to record the stress change in the overlying strata in real time during coal mining. The effect of the equipment connection is depicted in Figure 3.

\subsection{Analysis of Test Results}

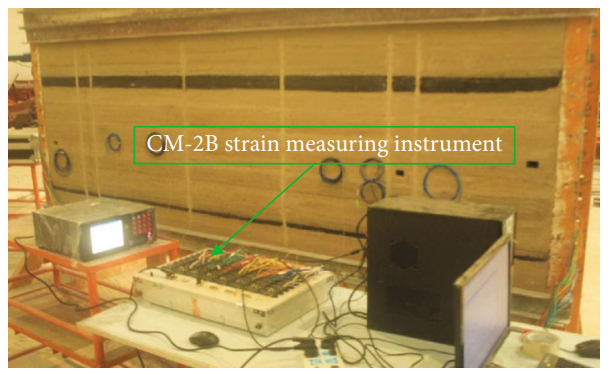

FIGURE 3: Effect diagram of model observation equipment.

3.3.1. Migration Law of Overlying Strata during Mining. In the early stage of mining, the overlying strata moved downward with coal seam mining, and the movement was slow. As the working face was continually excavated, rock fissures developed gradually, rock strata bent and sank, and tensile failure occurred, leading to rock collapse. At this time, the height from which the rocks fell was small, as depicted in Figure 4(a). With continuous mining of the coal seam, the overlying strata also moved toward the goaf. The fissures of the strata developed, the strata broke again, and the falling height increased to $5 \mathrm{~m}$, as depicted in Figure 4(b). When the working face was continually excavated $15 \mathrm{~m}$ forward, the main roof was broken periodically, and vertical and horizontal cracks appeared in the front and on the roof of the working face, respectively. At this time, the advancing distance of the working face was $70 \mathrm{~m}$, as illustrated in Figure 4(c). Therefore, the periodic fracture step of the main roof was approximately $15 \mathrm{~m}$.

The continuous excavation of the working face led to increasingly intense movement of the overlying strata, the weak strata collapsed with mining, and the main roof was broken periodically. Owing to the various properties of the strata, bed separation with a length of approximately $300 \mathrm{~mm}$ and a height of approximately $10 \mathrm{~mm}$ appears among the various strata above the main roof, as depicted 


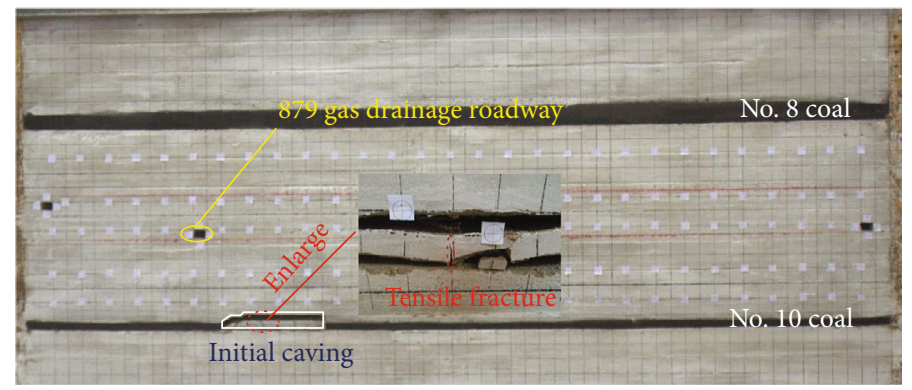

(a) Excavation at $35 \mathrm{~m}$

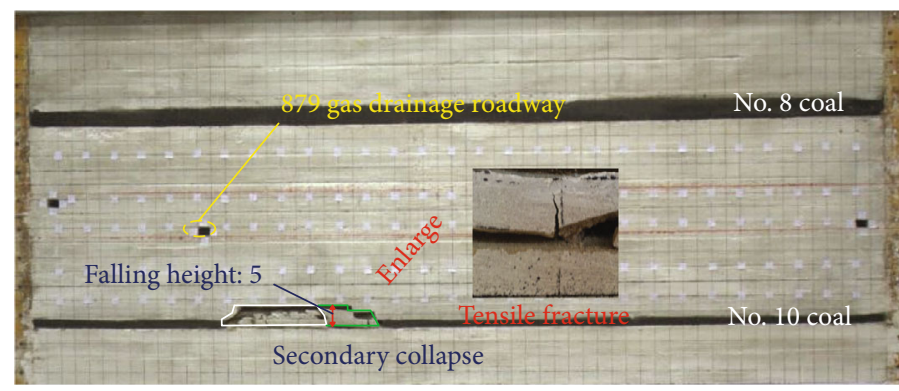

(b) Excavation at $55 \mathrm{~m}$

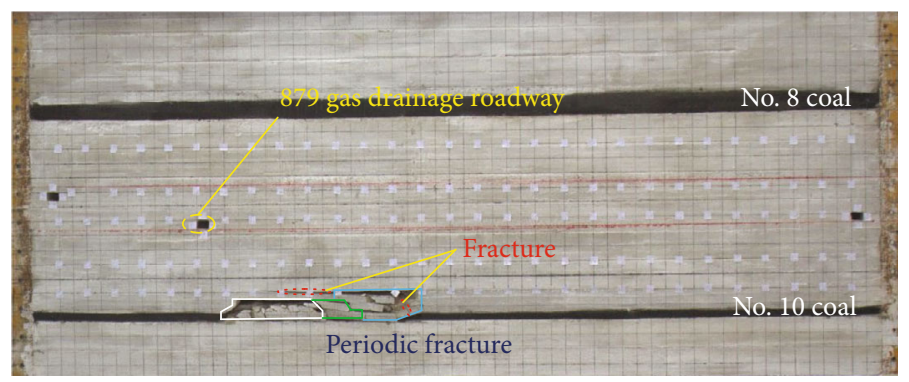

(c) Excavation at $70 \mathrm{~m}$

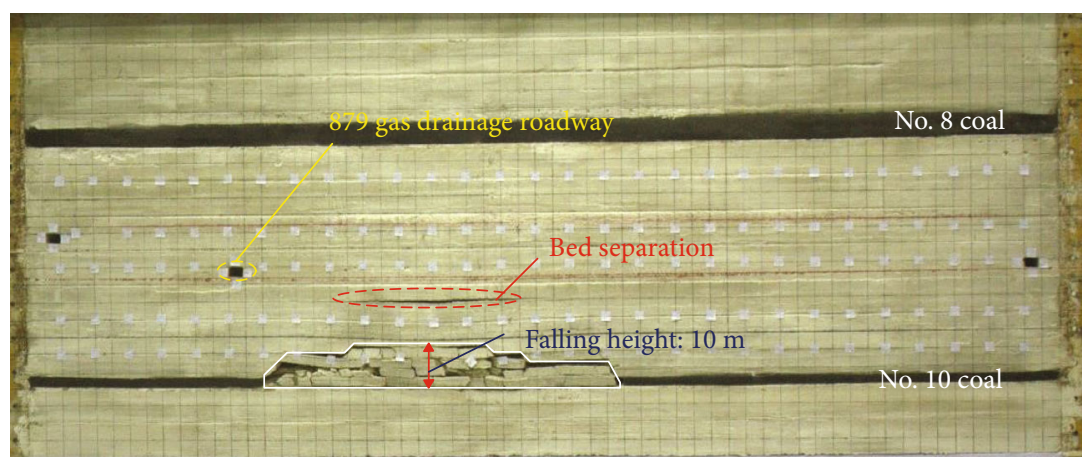

(d) Excavation at $105 \mathrm{~m}$

Figure 4: Continued. 


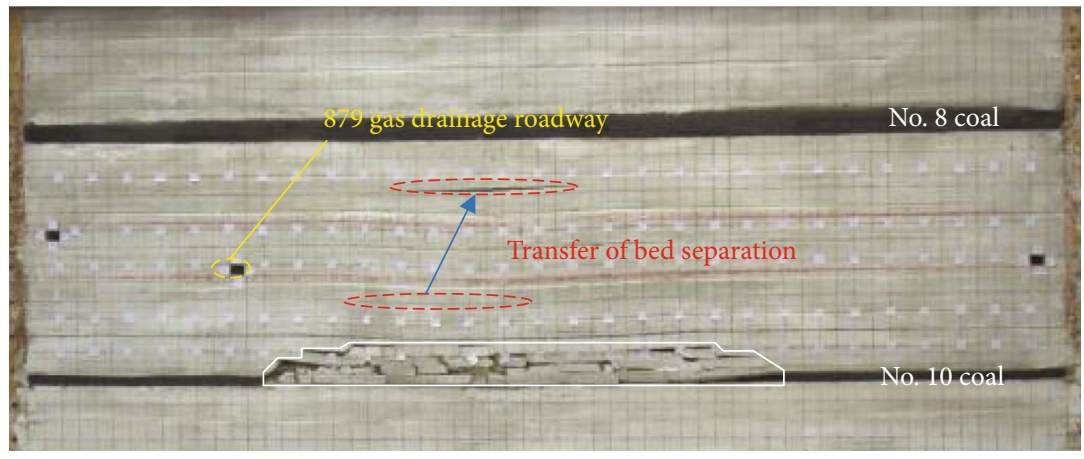

(e) Excavation at $150 \mathrm{~m}$

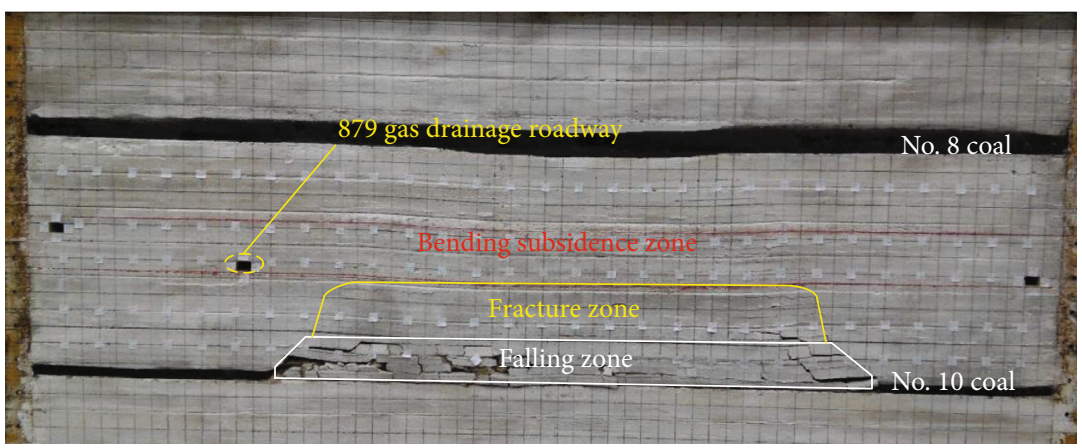

(f) Excavation at $180 \mathrm{~m}$

FIGURE 4: Movement characteristics of overlying strata during mining.

in Figure 4(d). As the working face was continually excavated further, the overlying strata further bent and sank, and the bed separation gradually closed and developed upward. As depicted in Figure 4(e), the deformation and movement of the strata began to affect the roadway horizon, and the strata moved and deformed toward the goaf, leading to tension in the surrounding rock on the right side of the roadway, causing small vertical tension cracks. When the working face was excavated up to the terminal line, as depicted in Figure 4(f), fissures developed in the rock surrounding the roadway, which exhibited asymmetric characteristics.

\subsubsection{Stress Distribution Law of Overlying Strata under} Mining. Owing to the mining of the coal seam, the original stress equilibrium state of the overlying strata was broken, the stress was redistributed, and the vertical stress concentration appeared at the coal wall of the working face. In the initial stage of mining, the stress concentration area was small. As depicted in Figures 5 and 6, when the excavation length of the working face was less than $55 \mathrm{~m}$, the stress concentration factor of the rock layer $33 \mathrm{~m}$ away from the roof of the working face tended to be 1 . The results indicate that when the excavation distance of the working face was less than $55 \mathrm{~m}$, the range of impact of the mining was the largest within $33 \mathrm{~m}$ of the roof, and the impact on the strata at $33 \mathrm{~m}$ of the roof and above was small. When the excavation length of the working face exceeded $55 \mathrm{~m}$, the scope of impact of the mining expanded. The impact gradually reached and crossed the strata where the roadway was located; the maximum value of the impact was reached on the strata $70 \mathrm{~m}$ above the roof, as depicted in Figures 7 and 8.

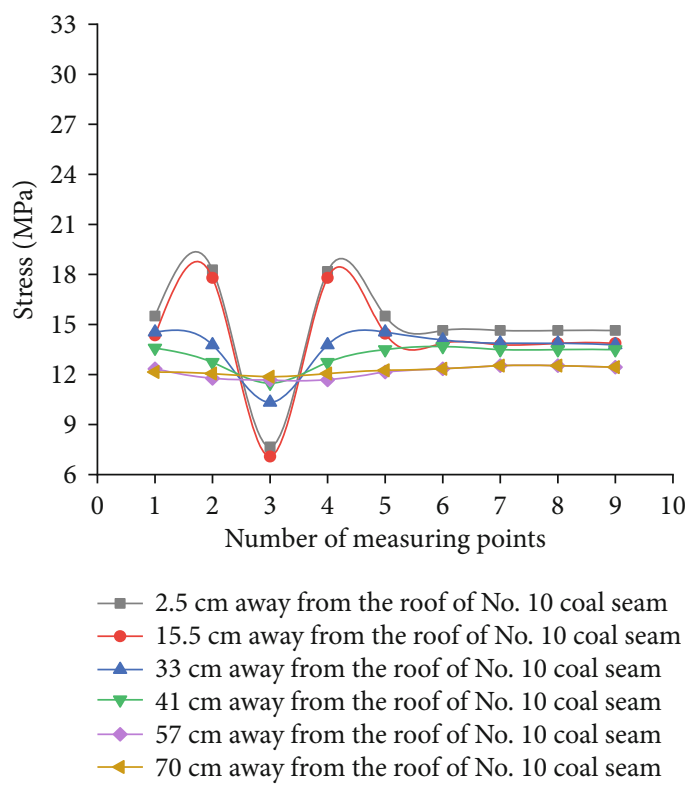

FIgURE 5: Stress diagram of working face mining at $35 \mathrm{~m}$.

Based on this investigation of overburden migration and stress distribution, the stress distribution during the mining process of the working face was summarized and analyzed. The results obtained from the monitoring and distribution of rock stress were compared with those of the model, and the stress distribution in each layer was determined. The stressed environment of the roof of the 879 gas drainage roadway can be described as follows: After the mining of 


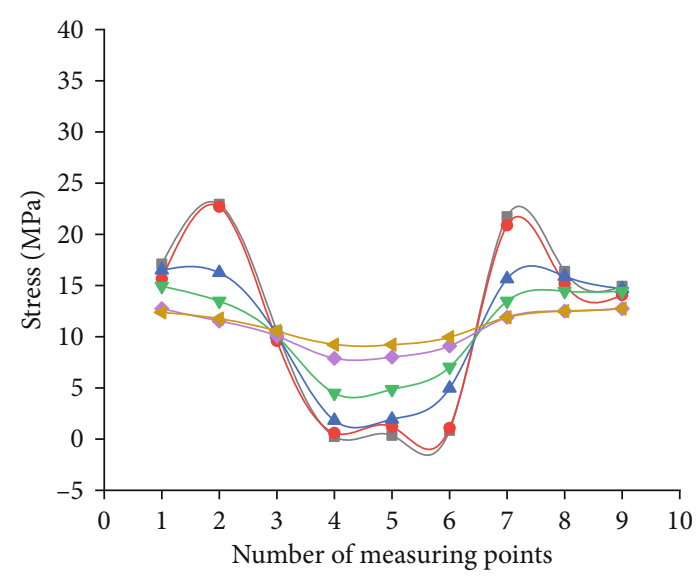

$\rightarrow-2.5 \mathrm{~cm}$ away from the roof of No. $10 \mathrm{coal}$ seam

$-15.5 \mathrm{~cm}$ away from the roof of No. 10 coal seam

- $33 \mathrm{~cm}$ away from the roof of No. 10 coal seam

$\rightarrow-41 \mathrm{~cm}$ away from the roof of No. 10 coal seam

$-57 \mathrm{~cm}$ away from the roof of No. 10 coal seam

$-70 \mathrm{~cm}$ away from the roof of No. 10 coal seam

Figure 6: Stress diagram of working face mining at $55 \mathrm{~m}$.

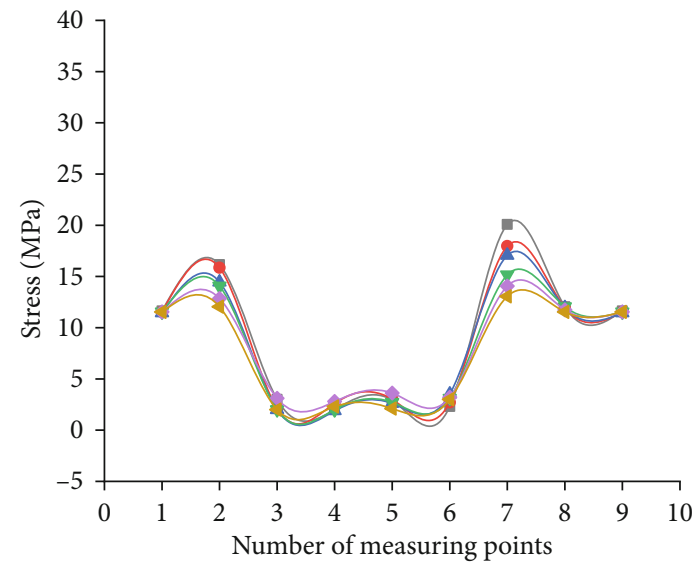

$-2.5 \mathrm{~cm}$ away from the roof of No. 10 coal seam

- $15.5 \mathrm{~cm}$ away from the roof of No. 10 coal seam

$-33 \mathrm{~cm}$ away from the roof of No. 10 coal seam

$\rightarrow-41 \mathrm{~cm}$ away from the roof of No. $10 \mathrm{coal}$ seam

$-57 \mathrm{~cm}$ away from the roof of No. 10 coal seam

$-70 \mathrm{~cm}$ away from the roof of No. 10 coal seam

FIGURE 7: Stress diagram of working face mining at $150 \mathrm{~m}$.

the II 1051 working face, the 879 gas drainage roadway in the upper part of the No. 10 coal seam lays in the stress-rising area of the overlying strata formed by mining. As illustrated in Figure 9, the stress concentration factor of the surrounding rock increased, and the roadway was strongly affected by mining. Thus, the roadway was prone to deformation and failure.

\section{Numerical Simulation Study on Stability of Upper Roadway under Upward Mining}

4.1. Establishment of Numerical Calculation Model. The finite difference numerical simulation software FLAC3D was used

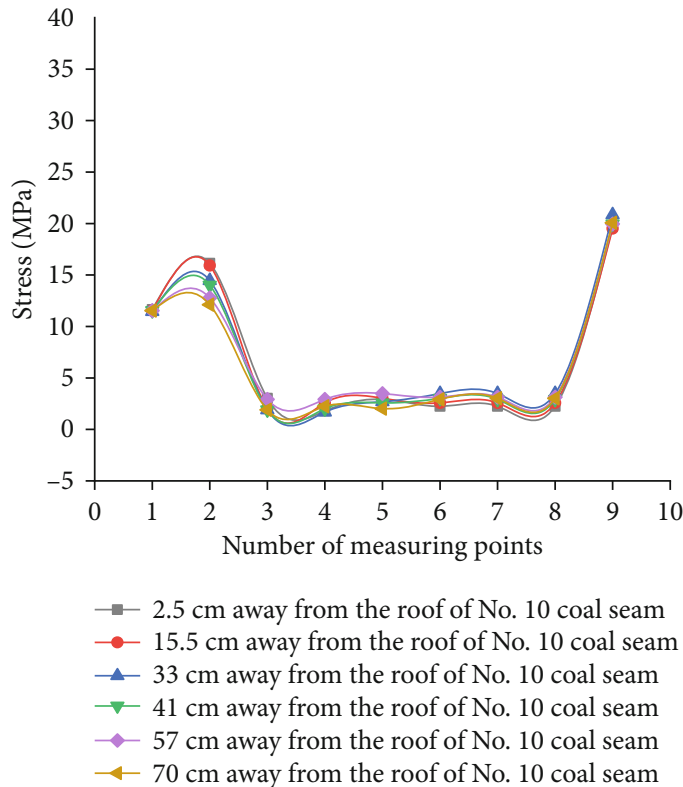

FIgURE 8: Stress diagram of working face mining at $180 \mathrm{~m}$.

to establish the required model based on the actual geological and mining technical conditions of the II 1051 fully mechanized face and the prior establishment of similar models. The model involves the studied coal seam, roadway, and its top and bottom plates. It simulates the dip angle between the coal and rock $\left(20^{\circ}\right)$ and the mining thickness of No. 10 coal seam $(2.5 \mathrm{~m})$. The model size is length $\times$ width $\times$ height $=$ $360 \mathrm{~m} \times 400 \mathrm{~m} \times 320 \mathrm{~m}$, which is divided into 9, 36, and 160 grid units, as depicted in Figure 10. The upper boundary of the model is defined as a free boundary, and the lower and left and right boundaries are defined as single-constraint boundaries to limit their horizontal displacement. The mechanical model adopts the Mohr-Coulomb strain-softening approach to reflect the property that the residual strength gradually decreases with the development of deformation after coal failure. A vertical load corresponding to the actual burial depth of the model was applied to the upper boundary of the model to simulate the stress exerted by the vertical pressure caused by other overlying strata. The physical and mechanical parameters of the model are listed in Table 1.

\subsection{Steps in Numerical Simulation}

(1) First, the relevant constraints of the model were defined, and the initial equilibrium operation was performed

(2) Second, the excavation balance among the transportation channel, track channel, and upper gas drainage roadway in the II 1051 fully mechanized working face was determined

(3) The working face was excavated step by step, and each excavation was $10 \mathrm{~m}$ deep

(4) Finally, comparative analysis and research were conducted on the model after the excavation operation had stabilized 


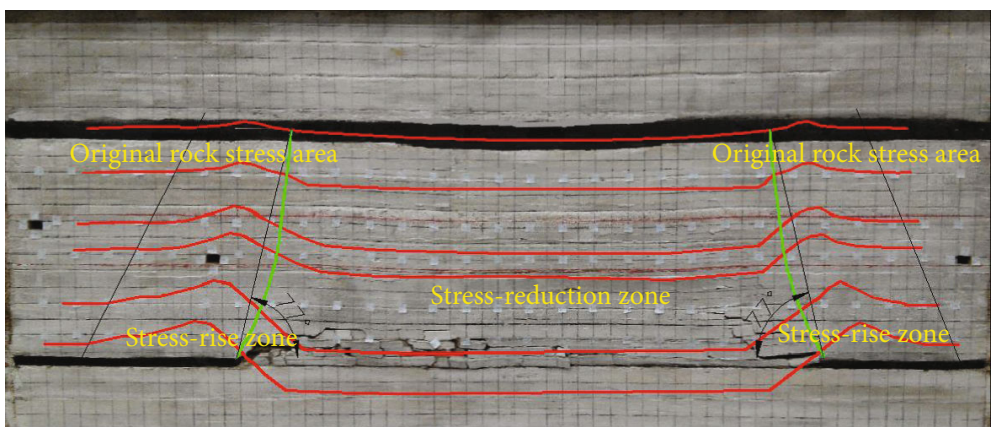

Figure 9: Stress zoning diagram.
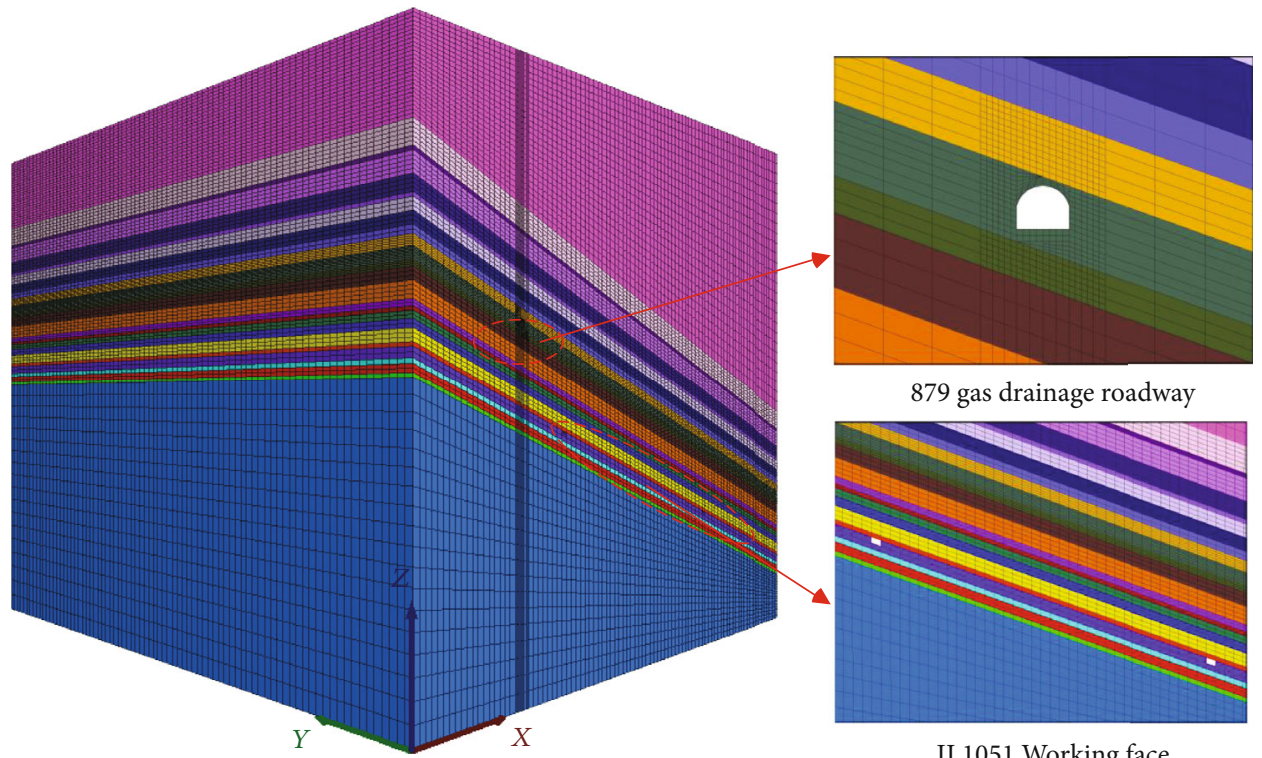

879 gas drainage roadway

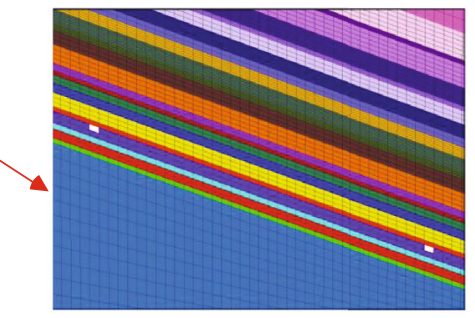

II 1051 Working face

Figure 10: Grid diagram of numerical model.

\subsection{Analysis and Discussion of Numerical Simulation Results}

4.3.1. Analysis of Characteristics of Failure Field of Rock Surrounding Roadway during Advancing of Working Face. Figure 11 depicts the distribution law of the roadway failure field $120 \mathrm{~m}$ from the initial position of the working face at various advancing distances.

As illustrated in Figure 11, in the early stage of the working face mining, the degree and scope of damage of the roadway floor and rock surrounding the roadway on either side were large. With the continuous advancement of the working face, the range of damage of the rock surrounding the roadway gradually increased. When the advancing distance of the working face was less than $60 \mathrm{~m}$, as shown in Figures 11(a) and 11(b), the degree and range of damage of the rock surrounding the roadway remained unchanged. When the advancing distance exceeded $60 \mathrm{~m}$, as shown in Figures 11(c)-11(h), the impact of the mining activities on the surrounding rock on either side of the roadway began to appear, and the degree and scope of damage began to increase. The increase in the range of the scope of damage of the roadway roof was small, and the degree and scope of damage were less than those of the floor and either side. It can be seen from the figure that the two sides of the roadway were damaged primarily by shear, and the damage depth was approximately $1.5-2 \mathrm{~m}$. The roof and floor of the roadway were damaged in the form of shear damage and tensionshear composite damage. The floor damage was the most significant, with a damage depth of $2.5 \mathrm{~m}$, and the roof damage was the least significant, with a damage depth of 1-1.5.

4.3.2. Analysis of Stress Change in Roadway during Advancement of Working Face. To analyze the stress distribution law of the rock surrounding the roadway in mining, the area with the maximum stress concentration on either side of the roadway was selected for data extraction to reflect the maximum stress applied on the roadway. The data in the figure were extracted from 10 to $400 \mathrm{~m}$ of the model; the data were taken every $10 \mathrm{~m}$. A total of 40 data points were captured from each survey line, and the data were extracted when the model simulated the excavation of $30,60,90,120$, 150, 180, 210, and $240 \mathrm{~m}$. Eight data curves were obtained for each side of the roadway, and the results are presented in Figure 12.

It can be seen from Figure 12 that the continuous advance of the working face led to a gradual increase in 
TABle 1: Parameters of physical and mechanical properties of the model.

\begin{tabular}{|c|c|c|c|c|c|c|c|}
\hline Rock name & Thickness (m) & Bulk (GPa) & Shear (GPa) & Coh. (MPa) & Fric. $\left({ }^{\circ}\right)$ & $\sigma_{\text {tension }}(\mathrm{MPa})$ & Density $\left(\mathrm{KN} / \mathrm{m}^{3}\right)$ \\
\hline Sand-shale interbeds & 2 & 0.13 & 0.12 & 0.86 & 32 & 0.31 & 2530 \\
\hline Fine sandstone & 4 & 1.05 & 0.68 & 1.28 & 38 & 0.52 & 2873 \\
\hline Siltstone & 2.5 & 0.13 & 0.12 & 0.86 & 32 & 0.31 & 2530 \\
\hline No. 10 coal & 5 & 0.25 & 0.10 & 0.50 & 28 & 0.17 & 1380 \\
\hline Mudstone & 2 & 0.30 & 0.17 & 0.48 & 26 & 0.15 & 2483 \\
\hline Medium sandstone & 6 & 0.55 & 0.43 & 1.28 & 38 & 0.52 & 2920 \\
\hline Fine sandstone & 4 & 1.05 & 0.68 & 1.28 & 38 & 0.52 & 2873 \\
\hline Siltstone & 3.5 & 0.54 & 0.41 & 1.10 & 34 & 0.41 & 2460 \\
\hline Mudstone & 2 & 0.30 & 0.17 & 0.48 & 26 & 0.15 & 2483 \\
\hline Fine sandstone & 3 & 1.05 & 0.68 & 1.28 & 38 & 0.52 & 2873 \\
\hline Sandy mudstone & 8 & 0.13 & 0.12 & 0.86 & 32 & 0.31 & 2530 \\
\hline Fine sandstone & 6 & 1.05 & 0.68 & 1.28 & 38 & 0.52 & 2873 \\
\hline Siltstone & 3 & 0.54 & 0.41 & 1.10 & 34 & 0.41 & 2460 \\
\hline Mudstone & 6 & 0.30 & 0.17 & 0.48 & 26 & 0.15 & 2483 \\
\hline Fine sandstone & 5 & 1.05 & 0.68 & 1.28 & 38 & 0.52 & 2873 \\
\hline Alumine & 4 & 0.06 & 0.04 & 1.00 & 32 & 0.36 & 2461 \\
\hline Siltstone & 6 & 0.54 & 0.41 & 1.10 & 34 & 0.41 & 2460 \\
\hline Medium sandstone & 6 & 0.55 & 0.43 & 1.28 & 38 & 0.52 & 2920 \\
\hline Fine sandstone & 2 & 1.05 & 0.68 & 1.28 & 38 & 0.52 & 2873 \\
\hline Mudstone & 8 & 0.30 & 0.17 & 0.48 & 26 & 0.15 & 2483 \\
\hline No. 8 coal & 10 & 0.25 & 0.10 & 0.50 & 28 & 0.17 & 1380 \\
\hline Fine sandstone & 2 & 1.05 & 0.68 & 1.28 & 38 & 0.52 & 2873 \\
\hline Mudstone & 12 & 0.30 & 0.17 & 0.48 & 26 & 0.15 & 2483 \\
\hline
\end{tabular}

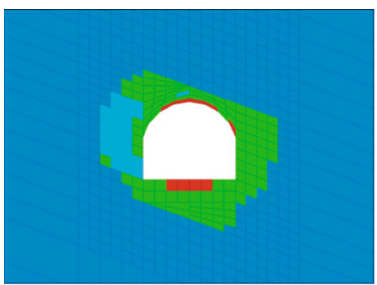

(a) Advance $30 \mathrm{~m}$

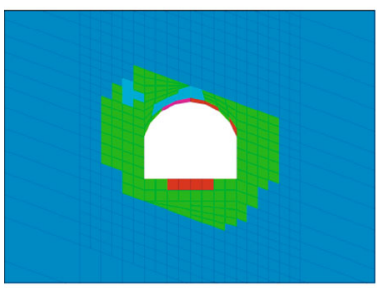

(d) Advance $120 \mathrm{~m}$

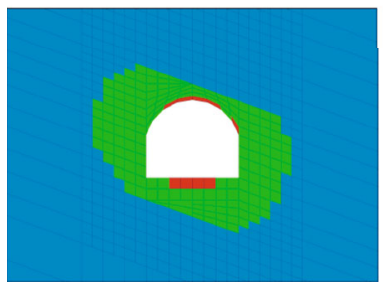

(g) Advance $210 \mathrm{~m}$

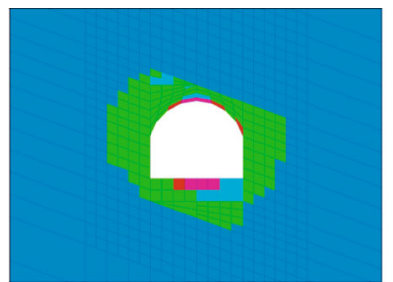

(b) Advance $60 \mathrm{~m}$

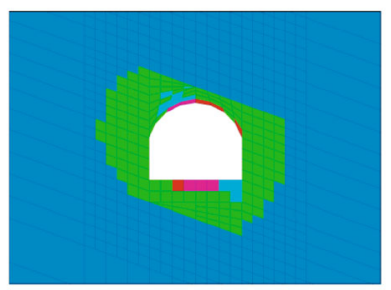

(e) Advance $150 \mathrm{~m}$

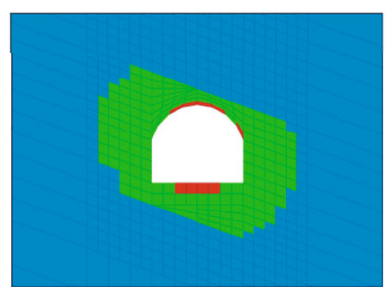

(h) Advance $240 \mathrm{~m}$

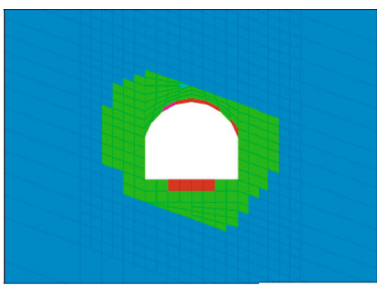

(c) Advance $90 \mathrm{~m}$

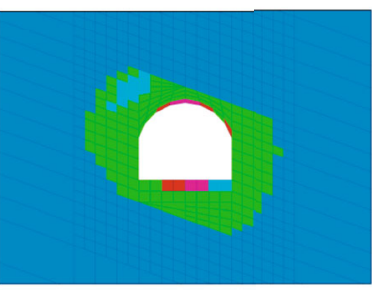

(f) Advance $180 \mathrm{~m}$

None

Shear-n shear-p

Shear-n shear-p tension- $p$

Shear-p

Shear-p tension- $p$

Tension-p shear-p tension-p

Tension-p tension-p

Tension-p

FIGURE 11: Distribution of characteristics of failure field of the surrounding rock at various positions from the working face. 


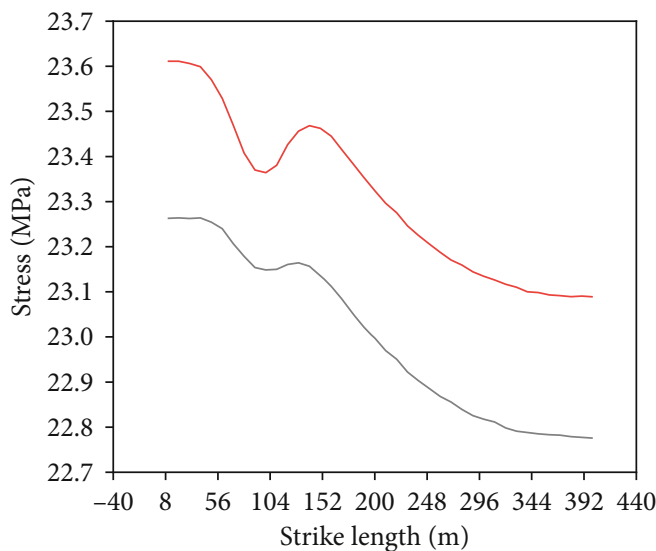

Left side of the roadway

Right side of the roadway

(a) Advance $30 \mathrm{~m}$

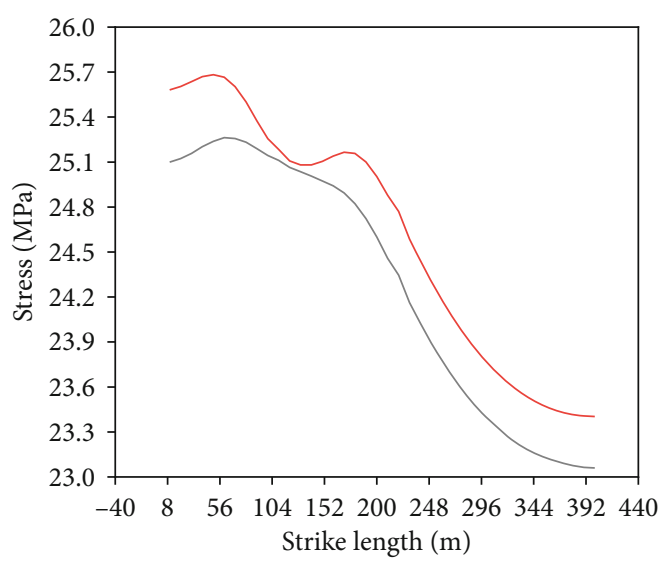

Left side of the roadway

Right side of the roadway

(c) Advance $90 \mathrm{~m}$

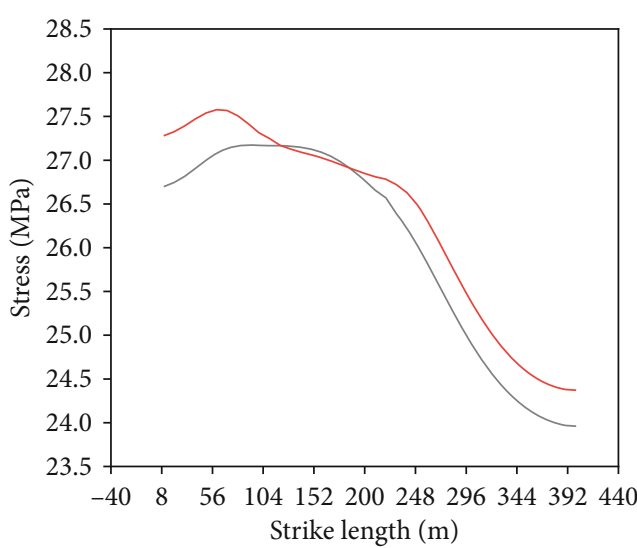

— Left side of the roadway

— Right side of the roadway

(e) Advance $150 \mathrm{~m}$

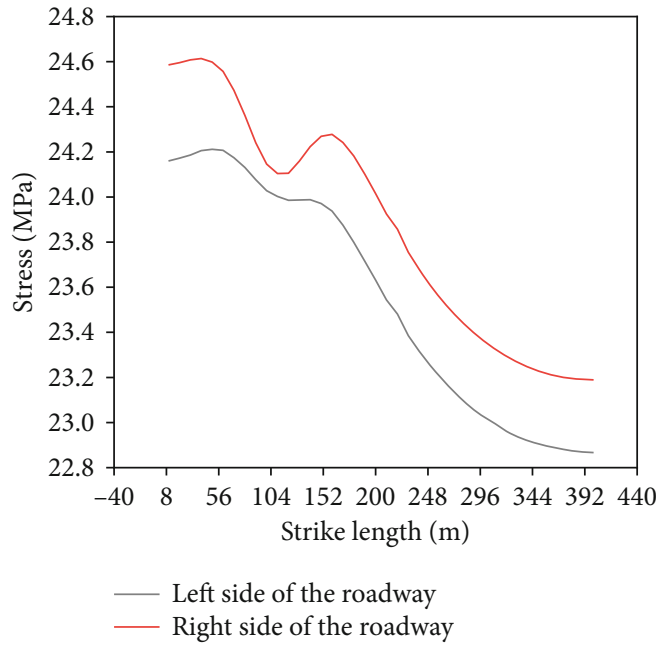

(b) Advance $60 \mathrm{~m}$

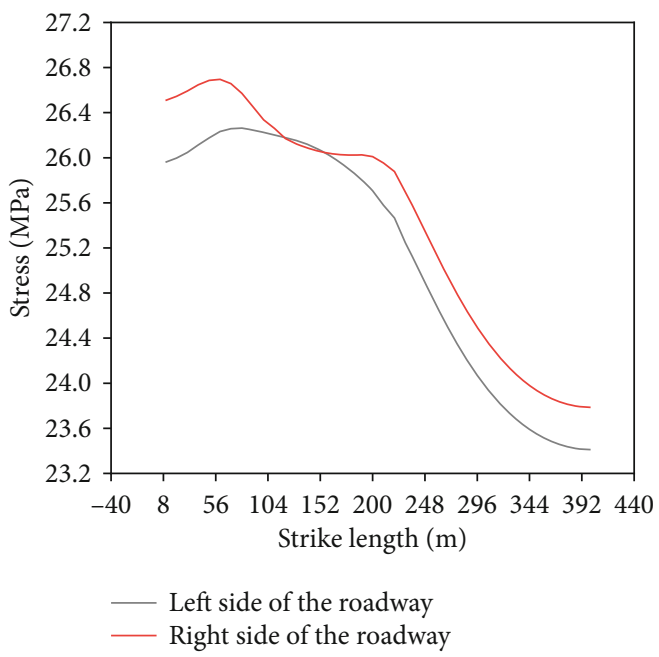

(d) Advance $120 \mathrm{~m}$

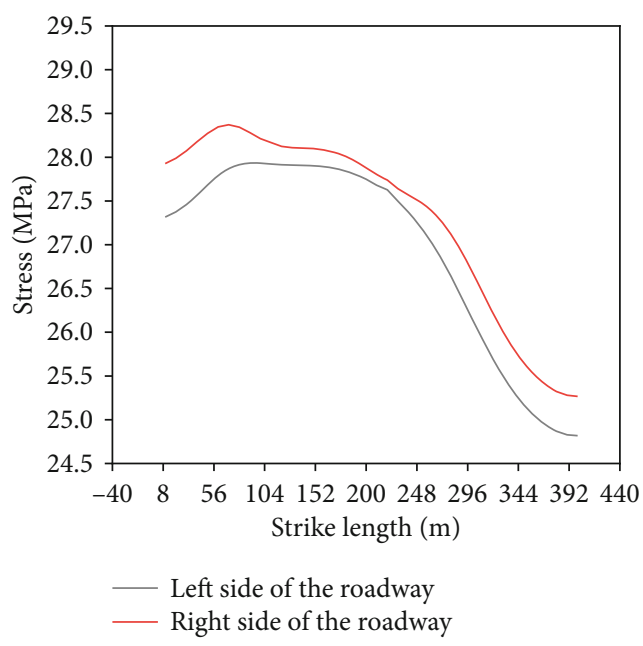

(f) Advance $180 \mathrm{~m}$

Figure 12: Continued. 


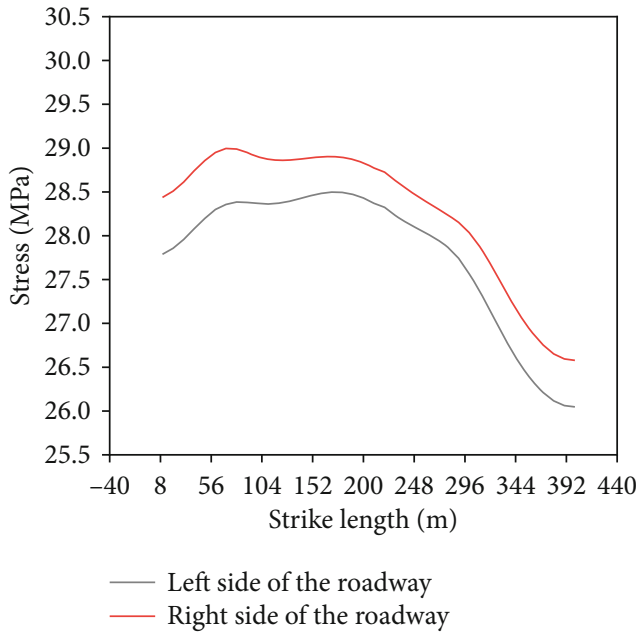

(g) Advance $210 \mathrm{~m}$

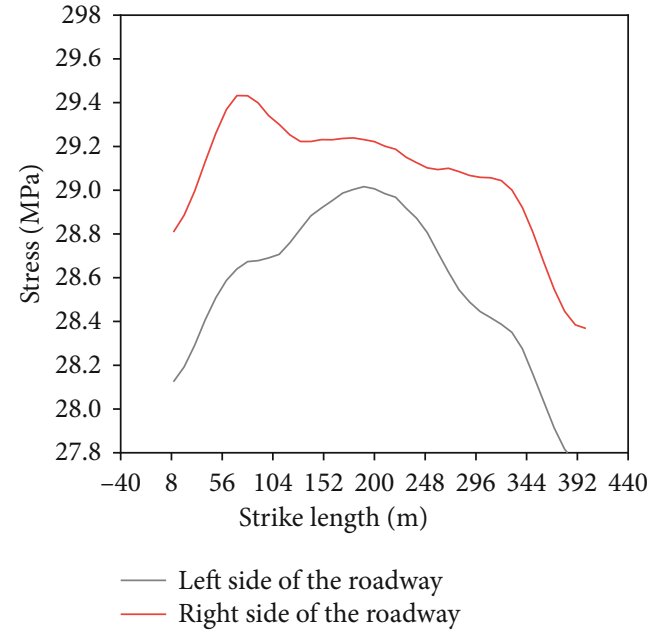

(h) Advance $240 \mathrm{~m}$

FIGURE 12: Vertical stress distribution on either side of roadway along strike under different advancing distance.

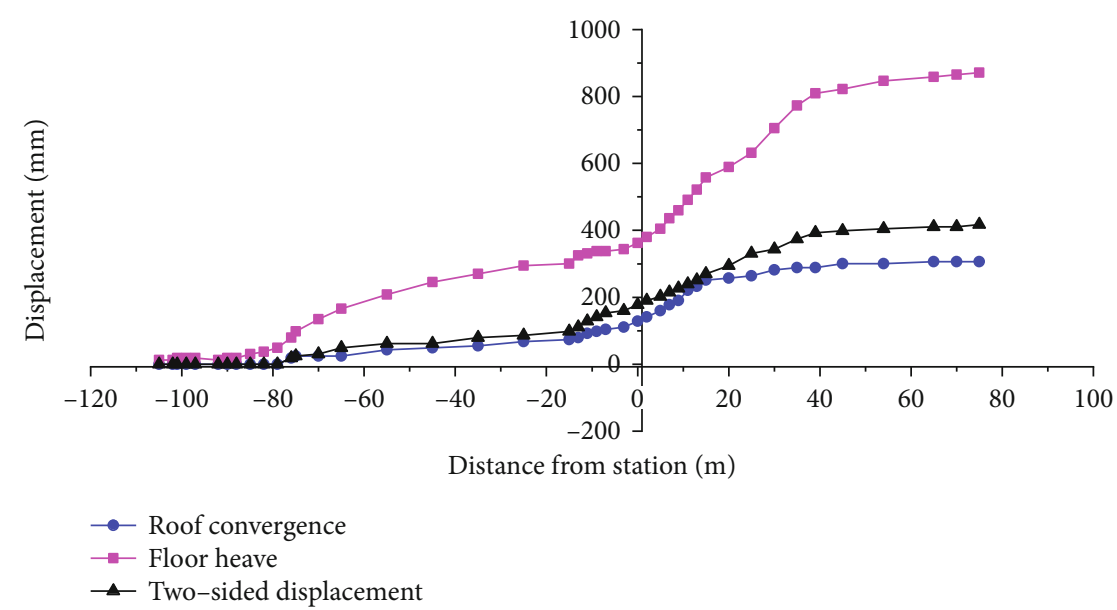

Figure 13: Deformation of roadway at various advancing distances.

the degree of stress concentration on either side of the roadway. The roadway was located in the mining abutment pressure-rising area, which also corresponded to similar simulation results; the degree of stress concentration on the right side of the roadway near the working face was greater than that of the left side. When the advancing distance of the working face was less than $60 \mathrm{~m}$, as shown in Figures 12(a) and 12(b), the stress on the rock surrounding the roadway exhibited no apparent change. At this time, the impact of mining did not affect the strata of the roadway. When the advancing distance of the working face was more than $60 \mathrm{~m}$, as shown in Figures $12(\mathrm{c})-12(\mathrm{~h})$, the stress on the surrounding rock began to increase, and the roadway was definitely affected by mining.

\subsection{Reasons for Deformation and Failure Characteristics and} Instability of Roadway. The natural caving method was used to manage the roof during the excavation process of the II 1051 working face. With the advance of the working face, the overlying strata moved continuously, forming "three zones" above the working face: the falling zone, fracture zone, and bending subsidence zone. With the increase in the falling height and the development of fractures, the bending subsidence of the overlying strata intensified. Because the upper roadway floor consisted of mudstone, the lithology was poor and was affected by the bending subsidence of the overlying strata; the floor is subjected to shear and tensile failures. With the continuous advancement of the working face, the impact of mining gradually affected the roadway horizon, stress concentration occurred on either side, and the damage gradually developed from the floor to either side, which led to aggravation of damage to the sides, primarily in the form of shear failure. Aggravation of the failure of the floor and either side led to breaking of the equilibrium state of the rock surrounding the roadway, which further caused subsidence of the roof. After the failure of the roof, the entire surrounding rock gradually became unstable, which further increased the scope of the floor failure and finally led to an increase in the failure of the entire surrounding rock field. 


\section{Measurement and Analysis of Roadway Deformation}

To determine the deformation characteristics and stability time of the roadway, the displacement observation station was set at an appropriate position in the roadway. To determine the appropriate roadway support technology and support time, the cross point method was used to observe the deformation of the roadway in the process of mining. The observation started in early June and ended in December. A measuring point was selected and set to 0 . A negative value indicates a distance near the measuring point, and a positive value indicates a distance away from the measuring point. By processing the observation data, the deformation curves exhibited in Figure 13 were obtained for the roadway roof subsidence, floor heave, and two sides.

As presented in Figure 13, with the advance of the II 1051 working face, the trend of roadway roof subsidence, floor heave, and either side moving closer was roughly the same. When the II 1051 working face was advanced to $60 \mathrm{~m}$ away from the measuring station, the impact of mining on the roadway was weak, and the deformation of the roadway was small. This conclusion was consistent with the results of the numerical simulations. When the working face was $20 \mathrm{~m}$ away from the measuring station, the speed of deformation of the roadway increased sharply. At this time, the roof subsidence, floor displacement, and two-sided approach were 60,300 , and $90 \mathrm{~mm}$, respectively. When the working face was pushed over the measuring station for $40 \mathrm{~m}$, the deformation rate of the roadway began to slow down, and the deformation of the roadway tended to be stable. At this time, the roof subsidence, floor subsidence, and two-sided approach were 300 , 800 , and $400 \mathrm{~mm}$, respectively. From the field measurement data, it can be seen that the 879 gas drainage roadway was affected by the mining of the lower working face, and the roadway deformation, particularly the floor heave, was evident. Therefore, floor heave control should be considered when selecting a roadway support scheme.

\section{Conclusion}

We studied and analyzed the deformation and failure characteristics of the overlying strata to understand the law that governs their impact on similar characteristics of the upper roadway and the instability mechanism of the roadway during the mining of the lower protective seam. For this purpose, the similarity simulation experiments and numerical simulations were used.

(1) At the initial stage of mining, the movement and deformation of the overlying strata had little impact on the upper roadway. When the working face was excavated at more than $55 \mathrm{~m}$, the movement and deformation of the overlying strata began to spread to the roadway, and the surrounding rocks on either side of the roadway began to produce asymmetrically distributed microcracks. With the continuous excavation of the working face, the range of impact of the mining stress also expanded. When the excava- tion reached the terminal line, that is, the working face was connected, the area impacted by the mining stress extended to $70 \mathrm{~m}$ above the roof roadway of the working face. At this time, the roadway lays in the mining stress-rising area, and the stress concentration factor of the surrounding rock increased

(2) Affected by the mining of the lower working face, the degree of damage of the surrounding rock of the roadway was intensified, and the two sides produced shear damage. The roof and floor appeared in the form of composite tension-shear damage, and the degree of damage to the floor was greater. The depth of the final damage to the floor was $2.5 \mathrm{~m}$, and the depth of damage to either side and the roof of the roadway was $1-2 \mathrm{~m}$. With the continuous advancement of the lower working face, the degree of concentration of stress on the surrounding rock gradually increased, and that on the right side of the roadway near the working face was greater than that on the left side

(3) With the advancement of the working face, the trends of roadway roof subsidence, floor heave, and either side of the roadway moving closer were roughly the same, indicating a dynamic trend of increasing slowly first, then increasing sharply, and finally becoming stable. Here, the floor deformation $(800 \mathrm{~mm})$ was the largest, followed by that of the two sides $(400 \mathrm{~mm})$, and the roof deformation was the smallest $(300 \mathrm{~mm})$. Therefore, floor heave control should be considered in the selection of the roadway support scheme

\section{Data Availability}

The experimental test data used to support the findings of this study are available from the corresponding author upon request.

\section{Conflicts of Interest}

The authors declare that there are no conflicts of interest regarding the publication of this article.

\section{Authors' Contributions}

Teng-Gen Xiong contributed to the conceptualization, methodology, and writing-original draft. Ju-Cai Chang contributed to the conceptualization, writing-review and editing, and funding acquisition. Kai He contributed to the formal analysis. Ya-Feng Su contributed to the resources. Chao Qi contributed to the visualization.

\section{Acknowledgments}

This work was supported by the National Natural Science Foundation of China (nos. 51774009 and 51874006), the Key Research and Development Projects in Anhui Province (no. 202004a07020045), the Colleges and Universities under 
Natural Science Foundation of Anhui (no. KJ2019A0134), and the Graduate Innovation Foundation of Anhui University of Science and Technology (no. 2020CX2011).

\section{References}

[1] J.-y. Jiang, Y.-p. Cheng, P. Zhang, K. Jin, J. Cui, and H. du, "CBM drainage engineering challenges and the technology of mining protective coal seam in the Dalong Mine, Tiefa Basin, China," Journal of Natural Gas Science and Engineering, vol. 24, pp. 412-424, 2015.

[2] R. Zhang, Y. Cheng, and L. Yuan, "Study on the stress relief and permeability increase in a special low-permeability thick coal seam to stimulate gas drainage," Energy Sources, Part A: Recovery, Utilization, and Environmental Effects, vol. 42, no. 8, pp. 1001-1013, 2020.

[3] Q. Tu and Y. Cheng, "Stress evolution and coal seam deformation through the mining of a remote upper protective layer," Energy Sources, Part A: Recovery, Utilization, and Environmental Effects, vol. 41, no. 3, pp. 1-11, 2018.

[4] L.-g. Wang, Z.-f. Wang, S.-r. Xu, W. Zhou, and J. Wu, "A field investigation of the deformation of protected coal and its application for CBM extraction in the Qinglong coalmine in China," Journal of Natural Gas Science and Engineering, vol. 27, pp. 367-373, 2015.

[5] K. Jin, Y.-p. Cheng, W. Wang, H. Liu, Z. Liu, and H. Zhang, "Evaluation of the remote lower protective seam mining for coal mine gas control: a typical case study from the Zhuxianzhuang Coal Mine, Huaibei Coalfield, China," Journal of Natural Gas Science and Engineering, vol. 33, pp. 44-55, 2016.

[6] F. Yang, Z. Ge, J. Chen, L. Cheng, H. Lei, and L. Zou, "A comprehensive gas extraction system coupling high-level suction roadway and boreholes for gas disaster prevention in closelyspaced multiple coal seams," Energy Sources, Part A: Recovery, Utilization, and Environmental Effects, pp. 1-14, 2020.

[7] C. Wang, N. Zhang, G.-c. Li, X.-l. Xu, D.-y. Qian, and N.c. Zhang, "Control principles for roadway roof stabilization in different zones during ascending mining, China," Journal of China University of Mining and Technology, vol. 41, no. 4, pp. 543-550, 2012.

[8] Z.-h. Jiao, G.-m. Tao, H. Wang, and Z.-g. Lu, “Overburden strata movement and fissure evolution in lower protective layer in Jincheng mining district, China," Journal of Mining and Safety Engineering, vol. 34, no. 1, pp. 85-90, 2017.

[9] Z.-y. Cao, X.-q. He, E.-y. Wang, and B. Kong, "Protection scope and gas extraction of the low-protective layer in a thin coal seam: lessons from the DaHe coalfield, China," Geosciences Journal, vol. 22, no. 3, pp. 487-499, 2018.

[10] Y.-s. Bai and Y.-q. Hu, "Overlying strata movement of below protective seam," Journal of Coastal Research, vol. 83, no. 10083, pp. 193-198, 2018.

[11] L. Shun, X.-h. Li, Y.-x. Mao, and C.-j. Li, "Time-domain characteristics of overlying strata failure under condition of longwall ascending mining," International Journal of Mining Science and Technology, vol. 23, no. 2, pp. 216-220, 2013.

[12] Z.-q. Xiong, C. Wang, N.-c. Zhang, and G.-m. Tao, “A field investigation for overlying strata behaviour study during protective seam longwall overmining," Arabian Journal of Geosciences, vol. 8, no. 10, pp. 7797-7809, 2015.

[13] C. Wang, N.-c. Zhang, Y.-f. Han, Z.-q. Xiong, and D.-y. Qian, "Experiment research on overburden mining-induced fracture evolution and its fractal characteristics in ascending mining," Arabian Journal of Geosciences, vol. 8, no. 1, pp. 13-21, 2015.

[14] J.-h. Xue, H.-p. Wang, W. Zhou, B. Ren, C.-r. Duan, and D.s. Deng, "Experimental research on overlying strata movement and fracture evolution in pillarless stress-relief mining," International Journal of Coal Science \& Technology, vol. 2, no. 1, pp. 38-45, 2015.

[15] J.-x. Tang, Y.-1. Li, Y.-j. Jia, and L. L. Sun, "Study on zoning of overburden strata and roadway deformation of ascending mining in thin coal seam," Sustainable Development of Natural Resources, vol. 616-618, pp. 505-509, 2013.

[16] H.-t. Zhang, Z.-h. Wen, B.-h. Yao, and X.-q. Chen, "Numerical simulation on stress evolution and deformation of overlying coal seam in lower protective layer mining," Alexandria Engineering Journal, vol. 59, no. 5, pp. 3623-3633, 2020.

[17] N.-z. Xu and L. Han, "Pressure-relief effect of coal rock body of long distance lower protective seam mined based on FLAC3D," Journal of Coal Science and Engineering, vol. 16, no. 4, pp. 341-346, 2010.

[18] H. Zhang, B. Jin, B. Huo, F. Zhu, X. Fu, and Y. Lu, "Analysis on pressure relief and deformation of overlying rock-coal as lower protective seam mine in Changping mine, China," Journal of Liaoning Technical University (Natural Science Edition), vol. 35, no. 3, pp. 225-230, 2016.

[19] K. Yang, X. He, L.-t. Dou, W.-j. Liu, L. Sun, and H.-s. Ye, "Experimental investigation into stress-relief characteristics with upward large height and upward mining under hard thick roof," International Journal of Coal Science \& Technology, vol. 2, no. 1, pp. 91-96, 2015.

[20] X.-y. Zhang, Q.-h. Ren, M. Tu, and Y.-c. Dou, "Fracture evolution characteristics of surrounding rock during ascending mining of closer coal seam in Panyidong Coal Mine, China," Journal of Mining and Safety Engineering, vol. 33, no. 2, pp. 191-198, 2016.

[21] A.-x. Liu, T. Shi-hao, F.-t. Wang, Y. Yuan, C. Zhang, and Y.w. Zhang, "Numerical simulation of pressure relief rule of upper and lower protected coal-seam in thin-protective-seam mining," Disaster Advances, vol. 6, pp. 16-25, 2013.

[22] W.-p. Huang, W.-b. Xing, Y.-s. Zheng, and C. Li, "Reasonable layout of roadways for upward mining technology of close coal seams, China," Chinese Journal of Rock Mechanics and Engineering, vol. 36, no. 12, pp. 3028-3039, 2017.

[23] H.-b. Liu and Y.-p. Cheng, "The elimination of coal and gas outburst disasters by long distance lower protective seam mining combined with stress-relief gas extraction in the Huaibei coal mine area," Journal of Natural Gas Science and Engineering, vol. 27, pp. 346-353, 2015.

[24] D. Qian, H. Shimada, T. Sasaoka, S. Wahyudi, and P. Pongpanya, "Stability of roadway in upper seam of deep multiple rich gas coal seams through ascending stress-relief mining," Memoirs of the Faculty of Engineering, Kyushu University, vol. 75, no. 2, pp. 59-80, 2015.

[25] J.-1. Xie, J.-1. Xu, F. Wang, J.-k. Guo, and D.-1. Liu, “Deformation effect of lateral roof roadway in close coal seams after repeated mining," International Journal of Mining Science and Technology, vol. 24, no. 5, pp. 597-601, 2014.

[26] W. Cheng, Z.-s. Du, N.-c. Zhang, and D.-y. Qian, "Study on surrounding rock control for mining roadway of the overlying protected seam in ascending de-stressed mining, China," Journal of Mining and Safety Engineering, vol. 29, no. 2, pp. 220225, 2012. 
[27] N. Zhang, L. Yuan, W. Cheng, J.-g. Han, and X.-l. Hu, "Deformation characteristics and stability analysis of roof roadway in destressed mining, China," Journal of China Coal Society, vol. 36, no. 11, pp. 1784-1789, 2011.

[28] Z. Zhou, C.-Q. Zhu, and Q.-F. Li, "Failure mechanism and stability control of roof roadway in fractured zone, China," Journal of the China Coal Society, vol. 42, no. 6, pp. 1400-1407, 2017. 